\title{
Study on the System of Penalty Substitution in Taiwan, China-Based on 494 Commutation Judicial Documents
}

\author{
Weiwei $\mathrm{Du}^{1}$ \\ ${ }^{1}$ School of law, Beijing Normal University, Haidian, Beijing, China \\ Correspondence: Weiwei Du. E-mail: duweiwei0634@126.com
}

Received: December 24, 2020

Accepted: January 8, 2021

Online Published: January 22, 2021

doi:10.5539/ass.v17n2p83

URL: https://doi.org/10.5539/ass.v17n2p83

\begin{abstract}
Although the penalty substitution system has not been established in mainland China, there is no lack of relevant discussion. Some scholars suggest that we should learn from the introduction of a commutation system to alleviate the disadvantages of short-term freedom penalty and the difficulty of fine penalty implementation; other scholars discuss the function and value of penalty substitution. In mainland China, short-term free penalty and fine penalty are statutory punishments for many crimes, and if the penalty replacement can be realized within a reasonable range, it can also alleviate the disadvantages of the execution of the penalty. The judicial system of Taiwan is rich in judicial practice and has a long time to revise. Based on legislative data and 494 judicial documents related to commutation in Taiwan, China, a comprehensive review of the penalty substitution system in Taiwan will help to explore the role and limitations of penalty substitution as an alternative to punishment.
\end{abstract}

Keywords: penalty substitution, fine, social labor, servitude

\section{Research Background and Problems}

The system of penalty substitution in Taiwan province refers to the replacement system of penalty which has been declared to be executed in the form of fine, social labor, servitude or admonition. If the penalty is changed to fine, social labor, labor or admonition, the punishment originally declared shall not be executed. The system of penalty substitution of punishment is widely used in Taiwan 's criminal law and judicial practice.

Looking at the research results of the penalty substitution system in Taiwan, China, it can be divided into the following three types: one is the research on fine of the penalty substitution. Some scholars put the penalty for changing the sentence into the system of fine penalty, The representative achievement is Zhang Mingwei's "Deconstruction of the interlaced problem between the combined punishment for several crimes and the fine for easy punishment"And Chen Baiyu's "on the interpretation of the court of justice concerning the combined punishment for several crimes -- Taking the interpretation of Shi Zi No. 144, 366, 662 and 679 as the discussion center"; The second is the research on the social labor of easy service, focusing on the relationship between the combined punishment of several crimes and the criminal execution of applying for the social labor of easy service; Thirdly, taking the short-term punishment system as a whole to study the influence of the penalty substitution system;Fourth, the due process of the public prosecutor's command and execution. In addition to Wang Shike's thesis on the fine system in Taiwan, China, there are two other papers published by Wang Shike. And Qiu Hongyun's "on the system of changing punishment". Looking at the research results of Taiwan scholars, there is no systematic analysis of judicial documents, and judicial practice is the field that can best reflect the limitations of the penalty substitution system and countermeasures.

There are many references to "Yi Xing" in the papers of mainland scholars, but the meaning is not exactly the same. Some mean that Emperor Wen of Han Dynasty abolished corporal punishment in ancient China. It also refers to the change of penalty, It is similar to the system of penalty substitution in Taiwan, China. In the face of the current situation of criminal justice practice in mainland China, some scholars put forward the idea of localizing the fine system, It is called for the establishment of the system of punishment for changing criminal cases to alleviate the disadvantages of the execution of short-term free punishment. In addition, the alternative measures of punishment proposed by the Italian scholar Fili, based on the law of crime saturation, covers the fields of economy, politics, science, legislation and administration, and gradually enters the field of vision of scholars. The judicial system of Taiwan is rich in judicial practice and has a long time to revise. Based on the legislative data of Taiwan and 494 judicial documents related to penalty substitution, a comprehensive review of 
the penalty substitution system in Taiwan is conducive to exploring the role and limitations of the alternative punishment.

\section{Legislative Evolution of Penalty Substitution System in Taiwan, China}

With the development of Taiwan society, including the change of monetary policy and legal concept, the penalty substitution system in Taiwan has been revised many times. The revised contents are reflected in the following three aspects: The first is the types of penalty substitution. In the criminal law implemented in 1928 in Taiwan, it was stipulated that "commutative imprisonment" should not exceed six months from the date of implementation. If a fine is paid within the term of imprisonment, the date of imprisonment shall be deducted according to the amount paid and the standard set by the magistrate. Affected by the social and economic situation in Taiwan, the number of people applying for the fine of penalty substitution has decreased. In 2008, Article 41 of Taiwan 's Criminal Law added the provision of "easy to serve social labor". "Easy to serve social labor" is applicable to those who have been sentenced to freedom for less than six months and have not applied for the change of fine or have not been allowed to change the fine from the beginning.

Secondly, it is about whether the punishment can be changed after the punishment for several crimes should be executed. Item 2 of Article 41 of Taiwan 's criminal law has undergone three revisions: the first amendment was made in July 2006. Before the amendment, it was "several crimes which are combined and punished, all of which are in the situation mentioned in the preceding paragraph, and the same applies to those who should be executed for more than six months." After the amendment, it should be changed to "the provisions of the preceding paragraph shall also apply to the case where the penalty shall be executed within six months" If the penalty should be executed for more than six months, the fine shall not be changed. The second amendment was made in January 2009, which came into effect in September of the same year, adding the provision of " social labor". The third amendment came into effect on December 2009. It is specifically amended as follows: "the provisions of items 1 to 4 and 7 shall also apply to those who are liable to criminal fine or social labor for more than six months for several crimes punished simultaneously." If the penalty to be executed exceeds six months, the fine may still be changed.

Finally, it is the conversion standard of the fine. Taiwan began to issue new Taiwan dollars on June 15, 1949. After the implementation of the criminal law in 1995, 46 years later, the monetary unit of the fine stipulated in the specific provisions of the criminal law was changed to new Taiwan dollars. When the criminal law was amended in 1995, the amount of fine stipulated in the articles not amended in the specific provisions of the criminal law was increased to 30 times since the implementation of the criminal law amendment in 1995. However, the amount of new or amended provisions from June 26, 1983 to January 7, 1995 has been tripled. Item 1 of Article 41 of the criminal law, which was amended and implemented in 2006, changed from "conversion of one to three yuan for one day" to "conversion of one to three yuan for one day for one hundred and three hundred silver yuan for one day", and then increased to "conversion of one to three thousand new Taiwan dollars for one day", and deleted the condition of "obvious difficulties in execution due to physical, educational, occupational, family or other legitimate reasons". Comparatively speaking, the conversion standard before the amendment is lower, which is more beneficial to the prisoners, so the conversion standard before the amendment is applied. According to the penalty of each crime, the court decides that the penalty should be executed and tells the conversion standard of the fine.

\section{The System of Penalty Substitution System in Taiwan, China}

The system of penalty substitution of punishment in Taiwan refers to the system of substituting the declared punishment for execution in the form of fine, social labor, servitude or admonition. If the penalty substitution of punishment is completed, the original punishment shall be regarded as executed. Penalty substitution is a matter of consideration in sentencing, which affects the scope of sentencing without changing the nature of the crime. The principle of suiting punishment to crime and the legality of sentencing are the standards to judge the rationality of penalty substitution.

In the current criminal law of Taiwan, China, the earliest type of penalty substitution system is fine. The penalty substitution fine is a kind of penalty replacement method in which the amount of money prescribed by law is used to replace the declared penalty on the premise of meeting certain conditions of crime and punishment. According to articles 41 to 44 of the criminal law of Taiwan, the penalty for committing a crime less than "five years' imprisonment" is "not more than six months' fixed-term imprisonment or criminal detention" and "one day is converted to NT $\$ 1000,2000$ or $3000 "$.

With the development and change of society, the social labor of easy service is gradually brought into the system of easy punishment. Easy service social labor refers to the penalty replacement method of declaring punishment 
with social labor replacement according to the calculation standard stipulated by law when the applicable conditions are met. The subject who applies for social labor and obtains permission is called social laborer. Its social labor is unpaid labor service. According to the provisions of Article 41 and Article 42 of the current criminal law of Taiwan, China, under the circumstances of non combined punishment for several crimes, the maximum time limit for performing social labor in prison and criminal detention shall not exceed one year, and the date on which social labor is allowed to be easily served shall be taken as the base date for calculating the conversion of imprisonment to social labor; the maximum period of social labor for criminal punishment shall not exceed two years. In the case that the combined punishment for several crimes does not allow easy service of social labor, if some of the crimes have already been fined or the execution of social labor has been completed, the remaining sentence shall be executed; if some of the crimes have performed part of social labor, the social labor command book shall be cancelled, the remaining sentence period shall be executed, and the hours of social labor performed shall be offset. If a person is liable to social labor after being punished for several crimes, the term of performance shall not exceed three years. However, if the penalty to be executed does not exceed six months, the time limit for performance shall not exceed one year. The factors that determine the performance period of social labor include the number of social labor cases, the physical and mental health of social workers, family, work or study, etc. When the combined punishment for several crimes has been carried out, we should consider whether it is completed. For penalty substitution, the remaining labor has been performed, and the penalty should be executed for each part of the labor. The approval and settlement of the case are decided by the prosecutor. If the public prosecutor permits to serve the social labor easily, the execution section shall formulate the social labor command letter, and during the execution stage, the watchman shall track the implementation with the assistance of the nursing assistant. When the case is closed through social labor, the case closing report shall be handled by the guardian and examined by the prosecutor. It has formed a process of "deciding to implement - making written documents - tracking implementation - making written documents - deciding to close a case".

The third category in the penalty substitution system refers to a kind of penalty alternative way to replace the execution of fine, also known as servitude. Servitude is applicable in the following two situations: if the fine is not fully paid at the end of the two-month payment period and is unable to pay it in full, he is liable to take up labor; if the fine is not fully paid within two months according to his economic or credit status, he shall be paid in installments within one year after the expiration of the two-month payment period, and the rest shall be paid in installments within one year after the expiration of the two-month payment period The unfinished part shall be compulsorily executed or liable to servitude. There is a fixed substitution relationship between easy servitude and the corresponding fine, that is, the fine of NT \$1000, NT \$2000 or NT \$3000 is converted into one day of labor service. However, the term of service shall not exceed one year. Paragraph 7 of Article 51 of the criminal law of Taiwan region states: "if the majority of fines are declared, the amount of fines shall be fixed at the maximum amount of each penalty and below the combined amount of each penalty." If the conversion standard of the fixed amount of easy labor is different, the one with a longer term of labor shall prevail. Those who have served less than one day shall be exempted from calculation.

The current criminal law in Taiwan also stipulates "admonition". If the criminal motive of a prisoner who is detained or fined is obviously forgivable in public interest or morality, he can be admonished.

The transformation relationship between the fine and social labor reflects the following rules. Firstly, no matter whether the declared freedom penalty meets the applicable conditions of the commutation fine, they can apply for the alternative social labor; secondly, the cases that can't be fined easily can't apply for the changed social labor after they have been approved and partially performed; thirdly, whether it's the social labor directly approved for the declared freedom penalty, or through the conversion of the commutation fine After partial performance of the social labor of easy service, except that the fine of easy service can not be applied, the fine can be applied by social workers and paid in one time.

\section{The Judicial Status of the Penalty Substitution System in Taiwan, China-Based on 494 Penalty Substitution Judicial Documents}

As of October 11, 2019, there are 29725 commutative criminal laws that can be retrieved by the legal information retrieval system of Taiwan 's Judicial Yuan. Due to access restrictions, 494 judicial documents can be obtained from October 11, 2019, as early as 2016.

\subsection{Sample Content}

The judging time range reflected in the sample is from 2016 to 2019, as shown in the table below. 


\begin{tabular}{ccccc}
\hline particular year & 2016 & 2017 & 2018 & 2019 \\
Number of judgment documents & 1 & 2 & 13 & 478 \\
\hline
\end{tabular}

Among the penalty substitution cases, the number of local court cases was the largest, accounting for 74.1\%; Taiwan 's high court ranked second, accounting for 23.7\%; the number of Taiwan 's "Supreme Court" cases was only 10 , accounting for $2.0 \%$; the number of special court cases was the least, only 1 , accounting for $0.2 \%$. The number of cases in Tainan District Court and Kaohsiung District Court was the largest, accounting for $13.5 \%$ and $13.5 \%$ respectively.

Referring to the gist of Taiwan 's Supreme Court's criminal judgment No. 15 in the year of 2019, summary sentencing, in addition to restricting the effect of punishment to be a slight "false punishment", that is, in principle, it does not restrict the personal freedom of the defendant, or give a suspension of sentence, or easy to use fines and social labor, also restricts the notification of innocence, immunity from prosecution, inadmissibility or wrong jurisdiction. There is no lack of summary judgment in the judgment involving penalty substitution.

\subsection{Typological Analysis}

The types of penalty substitution include fine, social labor and labor. Both fine and social labor are the substitution of short-term freedom penalty, and easy servitude is the alternative execution of fine penalty. There are no relevant documents that can be admonished in the sample.

Although the original intention of penalty substitution of punishment is to alleviate the disadvantages of this punishment without changing the nature of the crime. However, in the judicial practice, there are many cases of applying for and granting the penalty substitution to commit new crimes again, or to evade the execution. The former involves the relationship between penalty substitution and probation, recidivism, aggravated punishment and other penalty systems. The details will not be repeated. The latter also includes the application of margin system. In Taiwan, China, the system of security deposit is applied to the penalty substitution punishment, which is aimed at the criminals who evade the execution. However, the amount of security deposit is negligible compared with the actual amount of penalty substitution fine. Referring to the criminal ruling No. 850 of the Yunlin District Court of Taiwan, China in 2019, the court supports the prosecutor's forfeiture of the deposit. The sentenced person may change the fine and pay in installments before escaping. The prosecutor requested that the original deposit and interest paid in should not be included. The deposit in this case is NT \$5000, and the first installment is NT $\$ 25000$ according to the amount of fine imposed by the court. According to the legal minimum of NT $\$ 1000$, the total payment is NT $\$ 180000$. As for the total amount to be paid, the deposit is only one thirty-six percent of the total amount.

For those who meet the conditions of the fine but fail to apply for the fine and are subject to social labor, six hours of social labor shall be converted into one day. If the case of easy service social labor has been taken into custody, the date of custody shall be converted into the number of social labor hours after it is converted into fixed-term imprisonment, criminal detention or the fine stipulated in Item 6 of Article 42 of the criminal law of Taiwan, China.

In the cases of social labor in Taiwan, China, the date of custody can not be converted into the quantity of social labor, but can be converted into fixed-term imprisonment, criminal detention or penalty substitution as a fine, and then the remaining part that needs to be executed is converted into the number of hours of easy service social labor.

In the process of the conversion between the fine and the social labor, the prosecutor's decision-making power is reflected in the following three points: In the case of fine penalty or the case of easy service fine, if the fine is not paid in full and the application for easy service of social labor is made, the prosecutor shall decide whether or not to serve the social labor easily; in addition, in the case of fine penalty or the case of changing criminal fine with permission, after performing part of the social labor, the prosecutor shall apply for the change of social labor If the fine is paid in full, it shall be submitted to the public prosecutor for approval, and whether to close the case shall be approved by the public prosecutor. Finally, if the public prosecutor wants to pay the fine in one time during the performance of social labor without applying for the fine before the case can be changed, the public prosecutor shall decide whether to approve the application.

The conversion standard of pecuniary fine and pecuniary servitude is usually NT $\$ 1000$ for one day. In only two of the judgments, the new and old laws concerning the standard of conversion were compared. Based on the principle of both the old and the light in criminal law, the amount of NT \$900 was converted to one day. Only 
one judgment recorded that the fine for easy servitude was converted to NT $\$ 3000$ per day.

The power of the court is limited to the instruction of the conversion standard of penalty substitution, and whether to grant the penalty substitution is at the discretion of the prosecutor. The court only has to examine whether the procedure of the prosecutor's judgment is in violation of the law, whether there is any error in the fact finding, whether the fact recognized by the prosecutor is reasonably related to the conditions specified in Item 1 and item 4 of Article 41 of the criminal law, and whether there is any situation that exceeds or exceeds the scope of the law. If so, the court can intervene. Otherwise, the professional judgment of the prosecutor should be respected. Except when necessary, the court shall also give notice in the ruling to grant the penalty substitution fine. In principle, it is not suitable for the prosecutor to judge whether the penalty is applicable to the penalty substitution fine.

The improper execution of the command by the prosecutor should refer to the illegal execution of the command by the prosecutor and the improper execution method. The prosecutor has specified the reasons for not changing the fine when examining the criminal's request, and there is no case of abuse of power or violation of the principle of proportionality, such as appointment of legal authorization, arbitrary, etc. So it is difficult to think that the exercise of discretion is illegal or improper. According to Article 484 of the criminal procedure law, improper execution of command means that the execution of the sentence or its method violates the law, or the victim suffers from major adverse interests due to improper disposal though it is not illegal.

Referring to the provisions of the procuratorial organs on the essentials of handling social work for easy service, cases that are prone to social work must be easily served with social labor requests and sent to the summons. The cases that may be fined for the penalty may be applied to simultaneous interpreting the requester to apply for a penalty or a direct fine. After the defendant arrives, he shall make a record of interrogation, asking whether he is requesting a penalty or a request for a change. Easy to serve social labor. If the public procurator rejects the request, he shall be informed to request another fine or to pay the fine directly. If no fine is requested or the fine is not paid, a command letter shall be made and put into prison for execution.

In order to alleviate the disadvantages of short-term free punishment, the fine and social servitude included in the system of penalty substitution system is set up first in legislation. The starting of the fine requires the victim to make a request to the prosecutor. In the time of economic depression, it is difficult to effectively realize the diversion of short-term freedom penalty by easy fine. Even if it is to relax the access conditions of the fine, it has no obvious effect, so the social labor of easy service has been added to the system of easy punishment. The content of social labor is of public welfare, which can promote the prisoners to play their useful value to the society, and they can also be exempted from prison while they work.

The purpose of combing the legislation and practice of penalty substitution system in Taiwan is to explore the value and limitation of commutation. It is necessary to make a rational judgment on the basis of a full understanding of the new system. If the introduction is really necessary, then we need to have a clear understanding of the risks that we need to avoid and overcome.

In terms of procedure, the prosecutor should give the prisoner the opportunity to make a statement including personal special reasons before making the decision of not penalty substitution. But the individual special cause itself is a general concept, only one document lists the relatively specific part of personal reasons in the judgment documents analyzed. That is, in Taiwan 's Xinbei district court, it listed "whether to apply for the fine of changing branch", "whether there is custody or bail before the determination of the case, whether the detained objects in the case are abandoned, whether the aggravation needs the assistance of the social Bureau, whether there are children under 12 years old who need to be cared for, and whether the fine can be paid in one time or by stages, etc. In judicial practice, throughout the listed documents, there is no change in the result of penalty substitution because of personal special reasons, which can refute that the original sentence is not executed, it is difficult to achieve the correction effect or to maintain the order of the law. In the judgment, for the benefit of the victim, the victim has the opportunity to state his opinions, and the setting of personal reasons is afraid to be a mere formality.

In the relevant judicial documents of Taiwan, China, we can see that the contradiction between penalty substitution and combined punishment for several crimes needs to be solved reasonably. At present, the proviso of Article 41 of Taiwan 's current criminal law gives the inmates the right of choice, that is, to choose between the two. Under the existing conditions, the contradiction between the two can be alleviated slightly. But for the inmates, there must be one of the two, and the rationality remains to be discussed. Taiwan adopts the method of court review. If the change of will does not seriously affect the execution procedure or violates the fairness of execution, even if it has been a long time since the previous decision, the prosecutor's original execution 
command decision will be revoked.

Interpretation No. 245 of the Judicial Yuan of Taiwan. Although the original intention of penalty substitution of punishment is to alleviate the disadvantages of this punishment without changing the nature of the crime. However, in the judicial practice, there are many cases of applying for and granting the penalty substitution to commit new crimes again, or to evade the execution. The former involves the relationship between penalty substitution and probation, recidivism, aggravated punishment and other penalty systems. The details will not be repeated. The latter also includes the application of margin system. In Taiwan, China, the system of security deposit is applied to the penalty substitution punishment, which is aimed at the criminals who evade the execution. However, the amount of security deposit is negligible compared with the actual amount of penalty substitution fine. Referring to the criminal ruling No. 850 of the Yunlin District Court of Taiwan in 2019, the court supports the prosecutor's forfeiture of the deposit. The sentenced person may change the fine and pay in installments before escaping. The prosecutor requested that the original deposit and interest paid in should not be included. The deposit in this case is NT \$5000, and the first installment is NT \$25000 according to the amount of fine imposed by the court. According to the legal minimum of NT $\$ 1000$, the total payment is NT $\$ 180000$. As for the total amount to be paid, the deposit is only one thirty-six percent of the total amount.

The judicial system of Taiwan is rich in judicial practice and has a long time to revise. Based on legislative data and 494 judicial documents related to commutation in Taiwan, a comprehensive review of the penalty substitution system in Taiwan will help to explore the role and limitations of penalty substitution as an alternative to punishment.

The system of penalty substitution in Taiwan, China refers to the replacement system of penalty which has been declared to be executed in the form of fine, social labor, servitude or admonition. If the penalty is changed to fine, social labor, labor or admonition, the punishment originally declared shall not be executed. The function of Taiwan 's penalty substitution system is to alleviate the disadvantages of the punishment without changing the nature of the crime, and at the same time, it is conducive to the return of the prisoners to society. However, the way to realize the theory is always full of thorns. The limitations exposed in judicial practice are the most important link in our rational understanding of this system. As for the total amount to be paid, the deposit is only one thirty-six percent of the total amount.

\section{References}

Article 43 of the current criminal law in Taiwan, China. Retrieved October 11, 2019 from https://law.judicial.gov.tw/FJUD/default.aspx

Chen, B. Y. (2013). On the judicial interpretation of the combined punishment for several crimes and the fine for easy Punishment -- Taking Shizi No. 144, No. 366, No. 662 and No. 679 as the discussion center. The Law Monthly, 64(5).

Criminal ruling No. 2132 of Taiwan High Court in 2019.

Huang, S., \& Li, Y. K. (2010). On the localization of the system of changing fine penalty. Journal of Zaozhuang University, (6).

Interpretation No. 245 of the Judicial Yuan of Taiwan.

Liu, B. X. (2011). On the due process of the public prosecutor's command and execution of the fine -- Discussion on the Supreme Court's ruling No. 899 in 2010. The Law Monthly, 62(6).

Liu, B. X. (2013). The relationship between the combined punishment for several crimes and the criminal execution of applying for easy social labor -- a discussion on the Supreme Court's ruling No. 496 of the Supreme Court in the year of 101. The Law Monthly, 64(6), 28-53.

Qiu, H. Y. (2016). On the commutation system. Department of law in Taiwan University.

Shi, J. H. (2004). On several issues of the deduction of the term of imprisonment. Science of law, (6), 87-93.

Wang, S. S. (2016). Review on the fine system of "Yike". Law Research Institute of School of law in Taiwan University.

Wang, Z. W. (2003). A textual research on the "Yi Xing" of emperor Wendi of Han Dynasty. Journal of Hubei University, (2), 90-92.

Wei, Y. W. (2018). Exploring the non penalty path of short-term freedom penalty in China: A comparative study based on empirical data. Journal of South China University of Technology, 20(3), 108-122.

Xue, Z. R. (2017). On the reform of the fine penalty system. NTU Law Journal, 47(2). 
Xue, Z. R. (2017). On the reform of the fine penalty system. NTU Law Journal, 47(2), 768.

Xue, Z. R. The reform direction of the sanction system for restricting short-term Freedom Penalty - with comments on the addition of Yi Fu social labor. Law review of Zhengda University, (116), 239-291.

Zhang, M. W. (2012). Deconstructing the cross problem between joint punishment for several crimes and fine for changing course. Taipei University Law Review, 82.

\section{Copyrights}

Copyright for this article is retained by the author(s), with first publication rights granted to the journal.

This is an open-access article distributed under the terms and conditions of the Creative Commons Attribution license (http://creativecommons.org/licenses/by/4.0/). 